\title{
Use Of ReCyCled Materials in Road Construction
}

\author{
Tatýrek Václav*1, Měštanová Dana² \\ ${ }^{1}$ Czech Technical University, Faculty of Civil Engineering, Thákurova 7, Prague 6, 166 29, Czech \\ Republic, vaclav.tatyrek@fsv.cvut.cz, https://orcid.org/0000-0002-8882-3452 \\ ${ }^{2}$ Czech Technical University, Faculty of Civil Engineering, Thákurova 7, Prague 6, 166 29, Czech \\ Republic, dana.mestanova@fsv.cvut.cz, https://orcid.org/0000-0001-8629-6516
}

\begin{abstract}
Today, the economic need to return millions of tons of previously used materials to the production process is recognized worldwide. This also applies to construction, where building materials can be used repeatedly. Use of recycled materials is an important tool for sustainable development and reaching a compromise between economic progress and the preservation of the environment. The article is focused on one segment of the issue, the road constructions. In the construction of roads, the optimal solution is to use an "old surface" to create a new one. This is particularly advantageous for roads with a surface of asphalt material. Thanks to its properties, it can be reprocessed and used in new packaged asphalt mixtures. In general, the aim is to use $100 \%$ recycled material. However, only a certain part can be used in the production of new asphalt mixtures, depending on the type of processing. The remaining volume of milled material is used to strengthen the subsoil of roads or for service roads.
\end{abstract}

\section{Keywords}

Road construction, public finance, recycled material, asphalt surface

\section{JEL Classification}

M21 Business Economics

Q56 Sustainability

DOI: https://doi.org/10.14311/bit.2021.01.06

Editorial information: journal Business \& IT, ISSN 2570-7434, CreativeCommons license (c) (i) published by CTU in Prague, 2021, http://bit.fsv.cvut.cz/ 


\section{Introduction}

The construction and repair of roads is highly dependent on public finances. The amount of money invested to construction / repair of roads by the state depends on the state's economy and the redistribution of public finances into individual budget items. For this reason, the amount of investment in transport infrastructure is different every year. Due to the coronavirus pandemic, it is difficult to estimate what the actual amount of investments will be in the future. Thanks to the fact that many road surfaces from asphalt surfaces, it is possible to reduce costs, for example, by using recycled material and thus repair more kilometers. Due to the fact that the road surface is exposed traffic loads and permanent climatic influences, the top layer, the so-called cover, is quickly damaged. Roads must be constantly repaired and the first phase of all repairs is the removal of the existing unsatisfactory cover, for asphalt roads create a milled material so-called recycled material. Its use is part of sustainable construction. The use of recycled material is also advantageous in earth bodies of roads and unbound layers, where the benefit is the saving of natural materials. [1]

\section{Methodology}

\section{Recycling processes}

One of the current topics in construction is recycling processes in the field of sustainable construction. These are essential for sustainable construction and strengthen environmental protection. To strengthen the protection of the environment and nature, it is necessary to:

- more efficient use of primary raw materials,

- prevention of illegal waste management,

- minimization of energy consumption during the life cycle of the building,

- reducing the environmental burden of production technologies,

- optimization of production and consumption (cement, concrete...),

- optimal choice of construction type,

- increasing the use and development of recyclable materials,

- increasing the service life and durability of structures.

For sustainable development, it is necessary to use environmentally friendly technologies in construction with lower demands on materials and energy, including the promotion of the use of recycled materials.

The impact of sustainable development is manifested in a number of areas: environmental quality $x$ economic efficiency and constraints $x$ social and cultural context. The traditional approach is 3 views: cost $x$ quality $x$ time. These views now need to be changed to reflect current requirements.

\section{Types of waste for recycling and recycling options}

Different wastes have different properties and their recycling is different. It is about:

- construction and demolition waste - concrete, masonry, tiles, ceramics, wood, glass, plastics, asphalt mixtures, metals, asbestos and excavated soil,

- wastes arising from the industrial production / extraction of primary raw materials - fly ash, slag, slag,

- municipal waste (15\% of all waste) - paper, plastic, glass, beverage cartons. 
The possibilities of recycling construction and demolition waste are:

- direct re-use on site,

- reintroduction into industrial production,

- processing into new building materials.

In accordance with sustainable development, the design and construction of buildings must also consider the possibilities of future recycling - this is an integrated approach to the design of the structure.

What is recycling - it is a way of using waste, by which the waste is reprocessed into products or materials for the original or other purposes of their use.

The term recycling or recirculation is defined as the possibility of returning to the process - reuse, re-cycle.

To fulfil the concept, the following criteria must be respected:

- technological

- organizational

- technical

- economic

- ecological

- legislative

- material

- socio-cultural

E.g. the environmental benefit of using recycled material is in the field of environmental protection. This involves a reduction in greenhouse gases, a reduction in air pollution and a significant reduction in landfills, where construction waste would otherwise be taken away and stored. But the key is to preserve natural resources for future generations (quarries, oil...).

Milled material and its use are possible in any of the following ways:

- production of asphalt mixture produced hot or cold,

- unbound base layer of road, airport, handling or similar traffic area,

- protective layer of the road or airport or similar traffic area,

- structure of the earth body of the road or construction of the railway line,

- unbonded construction layer of field and forest roads,

- hydraulically bound base layer of road, airport or similar traffic area or railway track structure [1].

\section{Analysis results}

\section{Factors limiting the use of recycled materials}

The amount of recyclable materials is related to the length of the road network, its extent, types of surfaces but also to the amount of financial resources intended for the construction and reconstruction of roads.

Only new material is often used exclusively for the construction of a new road, but during the life cycle there are cycles of processes associated with construction and subsequent recycling: implementation $x$ first use $x$ further use.

During these cycles, the inclusion of risks is also an important factor. These are mainly risks in the production of recycled materials and general negatives - such as dust, noise, transport, content of harmful substances, etc. 
The use of recycled material from asphalt surfaces is carried out by the recycling process in the following steps:

- demolition of a building or part thereof,

- preparation of construction material for crushing,

- pre-sorting and subsequent direct recycling process - crushing and grinding, sorting into fractions (mechanical disassembly by crushers),

- storage of recycled material,

- determination of its physical-mechanical properties.

\section{Economic reasons}

The economic reasons for using recycled material in new mixtures depend on the contractual relations with the investor. Investors often have doubts about the quality of the mixture that will contain the recycled material and therefore set out in the contractual conditions such requirements for the new asphalt mixture, which often exclude the possibility of using recycled material.

Ownership rights to the milled material play an important role. The owner of the recycled material is usually the general contractor or investor, and it depends on how these property rights are contractually regulated. The recycled material is therefore not owned by the entity that performs the milling work, i.e. the construction company. If the contractual relationship implies the possibility of using recycled material, it may be partly used on the road surface, or the recycled material may also be sold.

In the case of road reconstruction, it depends on the investor's request and economic assessment. The determination of the price per unit of measurement cannot be determined exactly. The cost depends on the thickness of the milled surface, its material, strength or even the distance of the order from the place of consumption. Transport costs in particular play an important role. This is influenced by the price of oil - for example, between 2000 and 2008 it rose from $\$ 27.4$ to $\$ 120$ per barrel. Such an enormous price increase was reflected in the price of laying the asphalt mixture by an increase of more than $200 \%$.

By using milled material, these costs can be significantly reduced. The savings in the use of milled material in the new mixture is mainly due to the reduction of costs on input materials - a substitute for aggregates. [2]

The decision is related to the process of pros and cons, both on the part of the investor and the contractor. For construction contractors, it is necessary to consider the following pros and cons when using recycled material, when:

PROS:

+ use of material that would otherwise have to be deposited in a landfill,

+ environmentally friendly solution,

+ cost savings for transport, for landfills.

CONS:

- higher consumption of binders,

- the need to buy really high quality material.

Milling technology is one of the most widely used technologies used to break and remove the existing road cover. Milling can be hot or cold. During hot milling, the road cover is preheated, which can then be removed more easily. This technology can only be used on asphalt covers, it cannot be applied to concrete covers. Cold milling results in higher noise, cutter wear and dust, which can be reduced by spraying the milling drum. Cold milling is generally a more commonly used technology than 
hot milling. Machines from a number of manufacturers - Wirtgen, Caterpillar or Bomag are used for milling. [3]

\section{Pricing for milling}

The determination of the price per unit of measure $(\mathrm{m} 2, \mathrm{~m} 3)$ cannot be determined exactly $100 \%$. The cost greatly depends on the thickness of the milled surface, its material, strength or even the distance of the order from the asphalt plant. In general, prices are set rather by comparison with competitors or on the basis of experience from previous seasons. The cost method of determining the price according to the cost of inputs is relatively complex in the case of milling, due to the variability of milling options for different surfaces and thicknesses.

The cost method could be used in a simplified form, where the most common samples of milling work according to the material would be determined on the basis of previous experience - e.g. milling of an asphalt surface $18 \mathrm{~cm}$ thick. For the samples, the average cost per unit of measurement would be determined and accordingly the price, which would then be applied to all thicknesses of the respective milling works according to the surface material. In this method, it would be important for milling work to determine fuel consumption, depreciation costs, staff, space rent, overheads, water costs or cutter wear costs. The wear costs of the cutter are the greatest unknown due to the fact that even with the same material e.g. asphalt, there can be different surface hardness. The cost of transporting and sweeping the road is usually quantified separately.

\section{Economic and ecological reasons for the use of recycled material}

Recycling and the use of recycled material reduce greenhouse gases from an environmental point of view, reduce air pollution and significantly reduce landfills, as otherwise "rubble" would be removed and stored.

Furthermore, from an economic point of view, there is a reduction in input costs for the production of a new road surface. This effect is mainly due to the rising price of oil. This price increase was reflected in the price of the asphalt mixture with an increase in the price between 2000 and 2008 from $\$ 35.5$ / $\mathrm{t}$ to $\$ 80 / \mathrm{t}$, which is an increase of about $225 \%$. Today, the price is around $\$ 100 / \mathrm{t} 1 \mathrm{t}$. However, the amount of this price may depend on the current economic situation.

By using milled material, these costs can be significantly reduced. The savings in using recycled material in a new asphalt mix depends on the percentage of this milled material in the newly packaged mix. E.g. the savings when mixing $25 \%$ of the recycled recipe into the newly formed packaged mixture is $12 \%$ per tonne of material to be re-laid. [4]

\section{Use of recycled material - acquisition of recycled material and ownership rights to it}

The benefits associated with the use of recycled material as aggregate for reuse in all layers of roads are proven. The use of this secondary raw material will contribute as much as possible to the improvement of the environment, both by preserving our natural resources for future generations (quarries, oil...) and by reducing the transport of building materials and the resulting exhalations, dust.

In common practice, the milling process proceeds as follows. The general contractor will order a company that deals with milling activities for milling the upper part of the road - asphalt or concrete. The company arrives, mills and pours the milled material into a loader, which, usually, is provided for it by the general contractor. The owner of the recycled material is usually the general contractor or investor. It depends on how these property rights govern the contractual relationship between them. However, the recycle is not owned by the milling company at any time. For this reason, he can no longer dispose of the recycled material in any way. If the owner is a general contractor, he will use it at his discretion. Either when creating a new road surface, for another construction purpose or sell recycled material. 
The process of recycling and reusing the material is shown in Figure 1

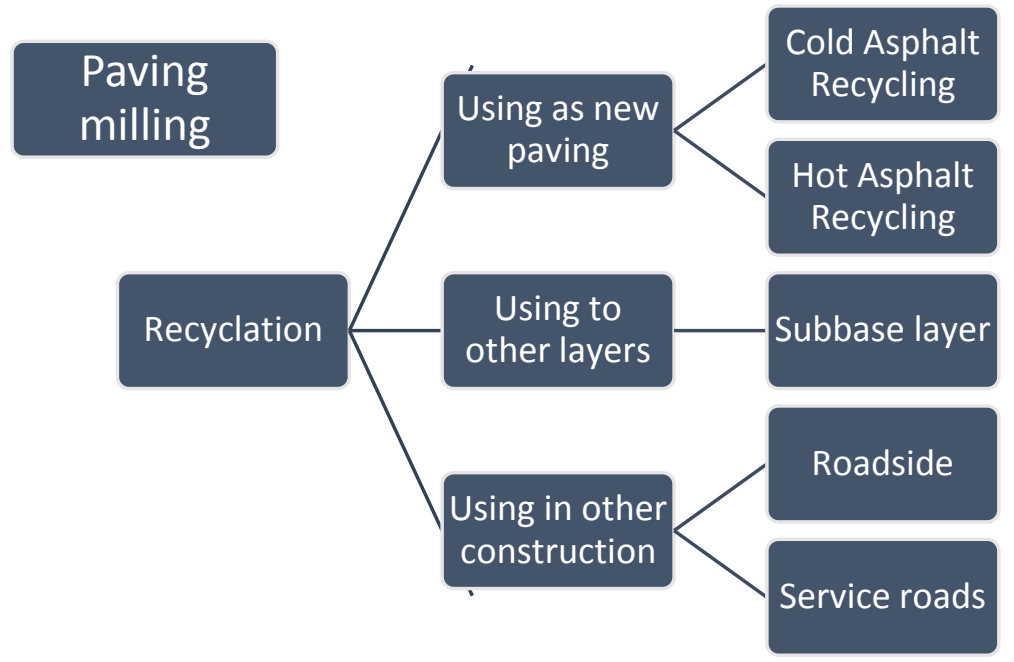

Figure 1: Methods of recycling milled material

\section{Recycling and utilization of milled material is handled in laboratories}

In recent years, the laboratory development of the use of recycled material in asphalt mixtures has shifted to the theoretical $100 \%$ recycled asphalt mixtures. But even so, the most modern asphalt plants are currently able to produce asphalt mixtures with a maximum of $80 \%$ recycled material [5].

Therefore, there is currently an effort to create legislative conditions to increase the maximum possible use of recycled material in asphalt mixtures so that it can be dosed into mixtures in amounts of up to $70(80) \%$. Possible use, resp. The permitted amount of recycled material in mixtures since 2009 is based on the ČSN 736121 standard.

\section{Use of recycled material}

Pre-crushed and sorted asphalt mixture is used in road construction in many ways. The main uses include:

- addition to new asphalt mixtures,

- further as aggregate into unbonded layers,

- as aggregate into layers bound by hydraulic binders,

- it is also possible, in a certain proportion with the embankment material, to be used in roadbed. [6]

When using recycled material as part of roadbed, it might seem at first glance that quality material is being wasted, which could be used much better. On the other hand, so many reconstructions of asphalt covers are currently being carried out that a large amount of this milled material is being formed, which would be processed for a very long time under today's conditions of use.

Also, the construction of high embankments requires a larger amount of local or purchased material, which may not always be available or economically advantageous. By using recycled material, cost reductions can be achieved. It is the use of recycled building material in soil stabilization that will reduce the amount of hydraulic binder added. The advantage in assessing the suitability of recycled material for the embankment of the earth body is that it is not necessary to meet the parameters for aggregates, but only for soils according to ČSN 73 6133, and most recycled materials meet this standard.

The use of recycled material in roadbed and unbound layers is therefore clearly possible and at the same time advantageous, especially in terms of saving natural materials. 


\section{Conclusion}

Recycling processes are essential part of environmental policy in the context of sustainable construction. In order to increase the volumes of recycled materials during the construction and repair of roads with asphalt surfaces, promotion and education of investors is needed. Whether or not recycled material will be used on a particular construction is primarily up to investors - construction customers. Customers do not yet support greater use of recycled material. Due to the volume of construction orders, considerable financial savings will be achieved by using recycled materials. At the same time, it is necessary for construction companies to make more use of these materials.

In general, the aim is to replace part of the natural aggregate with previously used material. That is why research into recipes for the production of asphalt mixtures in laboratories is so topical. At present, it is necessary to create legislative conditions to increase the maximum possible use of recycled material in asphalt mixtures. But despite these steps, the most modern asphalt plants are currently able to produce asphalt mixtures with a maximum of $80 \%$ recycled material.

The use of recycled material in construction makes sense and is generally advantageous.

It significantly contributes to the fact that in the future there will not be a situation where there will not be enough natural stone, which is an important part of asphalt mixtures, but also other building materials e.g. concrete.

In addition to the use of recycled material in asphalt mixtures, its use is also advantageous in roadbeds and unbound layers. Even with this use, there are savings in natural materials, reduction of transport costs, etc. [7]

\section{References}

[1] VARAUS, Michal. Recyklace netuhých vozovek - úvod do problematiky. VUT v Brně: STEPS 11, 2019

[2] HÝZL, Petr - ČSN 736141 Požadavky na použití R-materiálu do asfaltových směsí. VUT v Brně: STEPS 11, 2019

[3] SOLAŘOVÁ, Hana. Recyklace asfaltových vozovek za studena. Stavební technika [online]. 27.11.2007 [cit. 2020-02-19]. Dostupné z: https://www.stavebni-technika.cz/clanky/recyklace-a-asfaltovychvozovek-za-studena

[4] ZAJÍČEK, Jan. Použití recyklovaných materiálů při stavbě vozovek [online]. In: . 5/2019, s. 31 [cit. 2020 02-19]. Dostupné z: https://www.navrhovanivozovek.cz/

[5] ZAUMANIS, Martins, Rajib B. MALLICK a Robert FRANK. 100\% Hot Mix Asphalt Recycling: Challenges and Benefits. In: Transportation Research Procedia. 2016, s. 3493-3502. ISSN 23521465. online: doi:10.1016/j.trpro.2016.05.315

[6] Novela zákona o odpadech č. 541/2020 Sb.

[7] Zákon o životním prostředí č. 17/1992 Sb. 